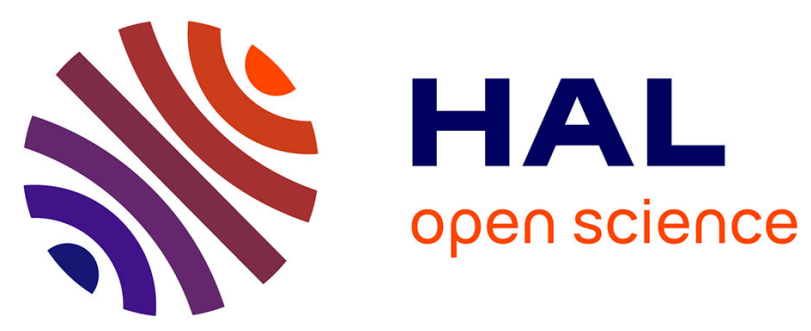

\title{
Is exogenous administration of IL-1ra (anakinra) likely to induce severe depression?
}

\author{
Annie-Pierre Jonville-Bera, Jean-Louis Guilmot, Gilles Aspe, Elisabeth
} Autret-Leca, Julie Magnant

\section{- To cite this version:}

Annie-Pierre Jonville-Bera, Jean-Louis Guilmot, Gilles Aspe, Elisabeth Autret-Leca, Julie Magnant. Is exogenous administration of IL-1ra (anakinra) likely to induce severe depression?. European Journal of Clinical Pharmacology, 2010, 67 (2), pp.213-214. 10.1007/s00228-010-0915-1 . hal-00631683

\section{HAL Id: hal-00631683 \\ https://hal.science/hal-00631683}

Submitted on 13 Oct 2011

HAL is a multi-disciplinary open access archive for the deposit and dissemination of scientific research documents, whether they are published or not. The documents may come from teaching and research institutions in France or abroad, or from public or private research centers.
L'archive ouverte pluridisciplinaire HAL, est destinée au dépôt et à la diffusion de documents scientifiques de niveau recherche, publiés ou non, émanant des établissements d'enseignement et de recherche français ou étrangers, des laboratoires publics ou privés. 


\section{Is exogenous administration of IL-1ra (anakinra) likely to induce severe depression?}

Annie Pierre Jonville-Bera, Jean-Louis Guilmot, Gilles Aspe, Elisabeth Autret-Leca, Julie Magnant

Annie Pierre Jonville-Bera $(\bowtie)$, MD

Regional Drug Monitoring Centre, Clinical Pharmacology Unit, University Hospital CHRU Tours, 2 Boulevard Tonnellé, F-37044 Tours, France

e-mail : jonville-bera@chu-tours.fr

Jean-Louis Guilmot, MD, PhD

Internal Medicine B Unit, University Hospital, CHRU de Tours, F-37044 Tours and François Rabelais

University, F-37032 Tours, France

Gilles Aspe, MD

Psychiatric Unit, Clinic of Vontes Chamgaul, F 37320 Esvres, France

Elisabeth Autret-Leca, MD, PhD

Regional Drug Monitoring Centre, Clinical Pharmacology Unit, University Hospital, CHRU de Tours, F-37044 Tours and François Rabelais University, F-37032 Tours, France

Julie Magnant, MD

Internal Medicine B Unit, University Hospital, CHRU Tours, F-37044 Tours, France.

Conflicts of interest None

Key Indexing Terms : anakinra ; adverse effects ; depression

\section{Word count: 596}




\section{Dear Sirs:}

Anakinra is approved for rheumatoid arthritis, but is also effective in patients with adult-onset Still's disease. We present what is, to our knowledge, the first case published of depression related to anakinra use.

A 43-year-old man had been diagnosed with Still's disease 18 months earlier. The diagnosis was based on chronic fever up to $39 \mathrm{C}$, chronic inflammatory arthralgias, myalgias, major inflammatory biological syndrome (CRP 200 to $300 \mathrm{mg} / \mathrm{L}$, fibrinogen $9 \mathrm{~g} / \mathrm{L}$, and neutrophils 20 to $30.10^{9} / \mathrm{L}$ ), and the exclusion of any other diseases. Blood cultures, testing for infectious agents, skin testing for tuberculosis, and antinuclear antibodies, as well as antineutrophil cytoplasmic antibodies were negative. The patient had no medical history of any diseases or other medical conditions. Prednisolone was administered at $1 \mathrm{mg} / \mathrm{kg} / \mathrm{d}$, which dramatically improved symptoms. When prednisolone was lowered to a dose of $0.5 \mathrm{mg} / \mathrm{kg} / \mathrm{d}$ per day, arthralgias and myalgias reappeared. Despite the introduction of methotrexate (20 mg weekly), prednisolone could not be lowered below $20 \mathrm{mg}$ daily. The patient's general status remained altered by disabling pain. One year later, anakinra was initiated (100 mg subcutaneous daily) and arthralgias and myalgias promptly disappeared. Prednisolone was progressively reduced to $8 \mathrm{mg}$ daily and methotrexate to $10 \mathrm{mg}$ weekly.

Six weeks after beginning anakinra, the patient complained of depressive symptoms. Two months later, clinical and biological signs of the disease were controlled but depressive symptoms had worsened. The patient was unable to work, and was hospitalized in a psychiatric inpatient unit due to major depressive disorder with suicidal ideation. As the patient had no personal or family history of depressive symptoms and no recent psychological trauma, a pharmacological cause was suspected.

Anakinra, the last drug introduced prior to the depressive disorder, was discontinued, and the patient was treated with cyamemazine $(75 \mathrm{mg} / \mathrm{d}$ for 3 days), clonazepam $(8 \mathrm{mg} / \mathrm{d})$, and citalopram $(20 \mathrm{mg} / \mathrm{d})$. Within a few days, depressive symptoms improved, allowing for a reduction in psychiatric treatment after 1 week. Anakinra was not reintroduced, and depressive symptoms did not recur following clonazepam and citalopram cessation.

This case report suggests a "probable" link between depression and anakinra, as there was a temporal relationship between the beginning of anakinra treatment and the onset of depressive symptoms, and between the discontinuation of anakinra and the regression of depressive symptoms. It should be noted that the depressive symptoms did not recur after withdrawing psychotropic drugs. The role of metothrexate can be excluded because its dosage had been reduced prior to the onset of the patient's depression and as depressive symptoms improved 
despite the continuation of methotrexate treatment. The role of prednisolone can also be ruled out as depressive symptoms improved despite the continuation of this treatment.

A literature search did not reveal any case report of depression related to anakinra use. However, in one case of Crohn's disease worsened by anakinra [1], the patient also reported depressive symptoms which disappeared after discontinuing anakinra therapy. Anakinra, a recombinant human interleukin-1 receptor antagonist (IL-1ra), acts as an IL-1 inhibitor and a significant association between high serum IL-1ra levels and depression was found in several studies [2]. Moreover, a significant positive relationship between serum IL-1ra level and the severity of depression was demonstrated [3] as documented by a higher risk of developing depressive symptoms over time in patients with high serum IL-1ra levels [4]. This cytokine could alter the activity of IDO (indoleamine 2,3-dioxygenase), a tryptophan metabolizing enzyme, thereby inducing changes in brain serotonine levels [5].A decrease in serotonin levels induced by IL-1ra could account for anakinra-related depression.

This first case report underlines the need to know this new side effect as it requires rapid anakinra cessation.

\section{References}

1. Carter JD, Valeriano J, Vasey FB (2003) Crohn Disease Worsened by Anakinra Administration. J Clin Rheumatol 9(4):276-277

2. Maes M, Bosmans E, De Jongh R, Kenis G, Vandoolaeghe E, Neels H (1997) Increased serum Il-6 and Il-1 receptor antagonist concentrations in major depression and treatment resistant depression. Cytokine 9(11):853-8.

3. Maes M, Vandoolaeghe E, Ranjan R, Bosmans E, Bergmans R, Desnyder R (1995) Increased serum interleukin-1-receptor-antagonist concentrations in major depression. J Affect Disord 36(1-2):29-36.

4. Milaneschi Y, Corsi A, Penninx B, Bandinelli S, Guralnik J, Ferrucci L (2009) Interleukin-1 receptor antagonist and incident depressive symptoms over 6 years in older persons: The InCHIANTI study. Biol Psychiatry 65(11):973-978.

5. Myint AM, Kim YK (2003) Cytokine-serotonin interactions through indoleamine 2,3-dixygenase: a neurodegenerative hypothesis of depression. Med Hypoth 61(5-6):519-525. 